\title{
Conservation and economic aspects of a combination of forestry-agricultural crops (Neolamarckia cadamba-Phaseolus vulgaris) and terrace systems in different slope classes
}

\author{
Karyati $^{1 *}$, Sri Sarminah ${ }^{1}$, Karmini ${ }^{1}$, Ali Muhammad Akbar ${ }^{2}$, Rifaldi Hermansyah ${ }^{3}$ \\ ${ }^{1}$ Faculty of Forestry, University of Mulawarman, Indonesia \\ ${ }^{2}$ Kayan Mentarang National Park Institute, Indonesia \\ ${ }^{3}$ Adindo Hutani Lestari Ltd., Indonesia
}

\begin{abstract}
ARTICLE INFO
Keywords:

Economic

Conservation

Hydro orological

Silvicultural

Slope

Article history

Submitted: 2020-12-16

Accepted: 2021-05-24

Available online: 2021-06-30

Published regularly: June 2021

* Corresponding Author

Email address:

karyati.hanapi@yahoo.com

\section{ABSTRACT}

The utilization of steep lands by planting forestry and agricultural species can provide benefits from soil-water conservation and economic aspects. The combination of planting Neolamarckia cadamba-Phaseolus vulgaris and terrace systems can increase land use values, such as soil conservation, crop production, and farmers' income. The aim of this study was to analyze silvicultural, hydro-orological, and economic aspects of a combination of forestry-agricultural crops ( $N$. cadamba $-P$. vulgaris) and terrace systems on two slope classes. Two study plots were established on a steep gradient (25-40\%) and a very steep gradient $(>40 \%)$. The results showed an annual increase in the average diameter and height of $N$. cadamba of $1.78 \mathrm{~cm}$ and $1.84 \mathrm{~m}$, respectively on the steep slope, and $1.68 \mathrm{~cm}$ and $1.53 \mathrm{~m}$, respectively on the very-steep slope. The surface run-off and erosion rate were lower on the steep ground compared to the very steep ground. Erosion hazard indices and levels on the plots in the steep slope and very-steep slope were categorized as low and very low; meanwhile, the erosion hazard class was I. The profit of $P$. vulgaris cultivation was IDR 9,360,000.00 ha ${ }^{-1}$ per cropping season on steep slope and IDR $6,480,000.00 \mathrm{ha}^{-1}$ per cropping season on very-steep slope. The planting of $P$. vulgaris as an intercropping plant to fill empty land in between $N$. cadamba can increase the economic value obtained from selling $P$. vulgaris in the short term until the leaves of the $N$. cadamba plant are linked. The combination of planting $N$. cadamba-P. vulgaris and terrace system on steep slopes is, therefore, more profitable not only from the economic perspective but also in lowering runoff and potential erosion rates than on very steep lands.
\end{abstract}

\begin{abstract}
How to Cite: Karyati, Sarminah, S., Karmini, Akbar, A. M., \& Hermansyah, R. (2021). Conservation and economic aspects of a combination of forestry-agricultural crops (Neolamarckia cadamba-Phaseolus vulgaris) and terrace systems in different slope classes. Sains Tanah Journal of Soil Science and Agroclimatology, 18(1): 98-106. https://dx.doi.org/10.20961/stjssa.v18i1.47708
\end{abstract}

\section{Introduction}

Climate change in terms of increasing frequency and intensity of floods and droughts, rising average air temperature, rising sea levels, and salt water intrusion affects agricultural activities in multi-facet ways (Agus et al., 2015). Most of the marginal lands are of low quality due to several limiting factors, such as large topographic slope; dominance of parent material; low nutrient content, organic matter and moisture content; and low or high soil $\mathrm{pH}$. According to data of 2015 of the Soil Research Institute under the Ministry of Agriculture, the marginal land area in
Indonesia reached 157,246,565 hectares. The increase in the conversion of agricultural land to non-agricultural land tends to reduce Indonesia's food security (Handayani et al., 2018). Although soil erosion activity caused by water is not a threat to food security but adds high costs to the agricultural sector in several countries (Panagos et al., 2018). The application of agroforestry system that combines forestry and agricultural crops may provide economic value as well as benefit of soil and water conservation since it can reduce soil erosion. The existence of forestry trees as the main crop and agricultural 
plants as intercropping can reduce surface runoff and soil erosion rates. Intercropping that covers soil surface is effective at restricting surface runoff during rainfall. The smaller surface runoff tends to reduce soil erosion rates.

The agroforestry systems are often adopted spontaneously by farmers. The application of agroforestry on sloping lands can be used as a viable approach to stabilize the soil. Improving integrated agroforestry systems is also a way to achieve sustainable livelihoods (Hoang et al., 2017). The practice of agroforestry systems on small-scale agriculture and hilly land has an important role in soil and water conservation (Wolde, 2015). The economic value of agroforestry products can be increased by applying appropriate marketing strategies, improved owner education, and economical management of agroforestry systems (Sollen-Norrlin et al., 2020). Knowledge on soil governance that is focused on implementing shared practices and alternative land management is applied based on farmers' knowledge and expectations (Cotler \& Cuevas, 2019). The indigenous soil conservation technology is useful as an effective conservation method. Some important activities, such as contouring, fertilizing, crop rotation, crop residues, cut-off drains and ditches can increase soil fertility and productive capacity, and reduce soil erosion. The annual loss of soil mass on steep slopes can be quite high, 114.59 tonnes ha-1 year $^{-1}$ (Mushir \& Kedru, 2012).

Surface runoff and soil erosion are higher on agriculture land than on forest land, while the nutrient content of sediment is higher on forest land than on agriculture land (Hidayat et al., 2012). Soil conservation techniques by utilizing vegetation can reduce surface run-off, soil erosion, and loss of nutrients. Soil conservation by planting crops sequentially with a strip system is an effective method to reduce run-off and soil erosion as well as prevent nutrient loss (Fuady et al., 2015). Agroforestry systems can be implemented in farming systems to reduce both surface runoff and soil erosion.

$N$. cadamba is one of the commercial native tree species that has good prospects for development in timber estate, former shifting cultivation, and low production forest areas (Wahyudi, 2012). Similarly, P. vulgaris is one of the popular agricultural products in Indonesia (Romadlon \& Nurisusilawati, 2019). The morphological, physiological, and anatomical characteristics of the seeds of white jabon (Neolamarckia cadamba) are more tolerant/resistant to waterlogging rather than drought stress (Sudrajat et al., 2015). In general, common beans (Phaseolus vulgaris) can adapt and recover gradually under conditions of drought stress until 8 days, but the growth of above-ground organs is hampered when experiencing a prolonged deficit of air for 12 days (Widuri et al., 2018). Planting Glycine max as an intercropping in agroforestry of Anthocephalus cadamba - G. max in the first year of first planting season needs IDR $11,019,000.00 \mathrm{ha}^{-1}$ per cropping season, and results in a total income of IDR 3,500,000.00 ha $\mathrm{ha}^{-1}$ per cropping season and a profit of IDR 7,519,000.00 ha- $\mathrm{har}^{-1}$ per cropping season (Karmini et al., 2017). Several studies on the silvicultural and economic aspects of applying different combinations of two plants or agroforestry and soil slopes have been reported (Karmini et al., 2017; Karyati et al., 2020; Karyati et al., 2018; Karyati et al., 2019; Sarminah et al., 2018). The growth parameters, such as diameter and height increments of forestry crops and crop production were reported to be higher on less steep land compared to the steeper land, while erosion rate, erosion hazard index, erosion hazard class, and erosion hazard level were found higher on soils with steep slopes than with less steep slopes (Karyati et al., 2020; Karyati et al., 2018; Karyati et al., 2019; Sarminah et al., 2018). The economic benefit of agroforestry system was obtained from crop yields in the short term while the forestry plants are expected to conserve the soil and water in the long term (Karmini et al., 2017). However, studies on the silvicultural, hydro orological and economic aspects of the application of agroforestry comprising $N$. cadamba- $P$. vulgaris and terracing systems on land with different slopes of land are still limited. Therefore, the aim of this study was to analyze the silvicultural, hydro orological, and economic aspects of planting with a combination of $N$. cadamba- $P$. vulgaris and terracing systems on different slopes. The information on growth, hydro orological, and economic aspects of the application of the combination of $N$. cadamba-P. vulgaris and terrace systems on steep to verysteep slope is crucial. Such information is needed for policymaking in choosing the suitable species of agroforestry and management of sloping lands, especially in tropical areas.

\section{Material and Methods}

\subsection{Study site}

The study was conducted from March to October of 2018 in the Educational Forest of Forestry Faculty, Mulawarman University, located in Tanah Merah Village, North Samarinda District, Samarinda City, East Kalimantan Province, Indonesia. The site is located at $0^{\circ} 25^{\prime} 10^{\prime \prime}-0^{\circ} 25^{\prime} 24^{\prime \prime}$ South Latitude and $117^{\circ} 14^{\prime} 00^{\prime \prime}-117^{\circ} 14^{\prime} 14^{\prime \prime}$ East Longitude.

\subsection{Data collection and analysis \\ 2.2.1 Experimental procedures}

Two trial plots, each of $10 \mathrm{~m} \times 10 \mathrm{~m}$, were established, one on a slope of $25-40 \%$ (steep) and the other on $>40 \%$ (very steep). The bench terrace with a terrace width of $2 \mathrm{~m}$, a length of $10 \mathrm{~m}$ and a water channel depth of $25 \mathrm{~cm}$ was made in the trial plots. Sixteen white jabon (Neolamarckia cadamba) plants were planted at a plant-to-plant spacing of $3 \mathrm{~m} \times 3 \mathrm{~m}$ in each plot. Jabon trees as forestry plants in this agroforestry system were planted for conservation of soil water; so it was planned not to cut down the trees. The Jabon plants were 6 months old. Meanwhile, bean ( $P$. vulgaris) was planted among the white jabon as intercropping by taking advantage of the empty spaces between the Jabon trees. It was expected that the beans could cover the soil surface to achieve the soil-water conservation function and provide economic value through the sale of the crops. Weeding, fertilising, and watering were done both for the jabon and bean (Figure 1). 


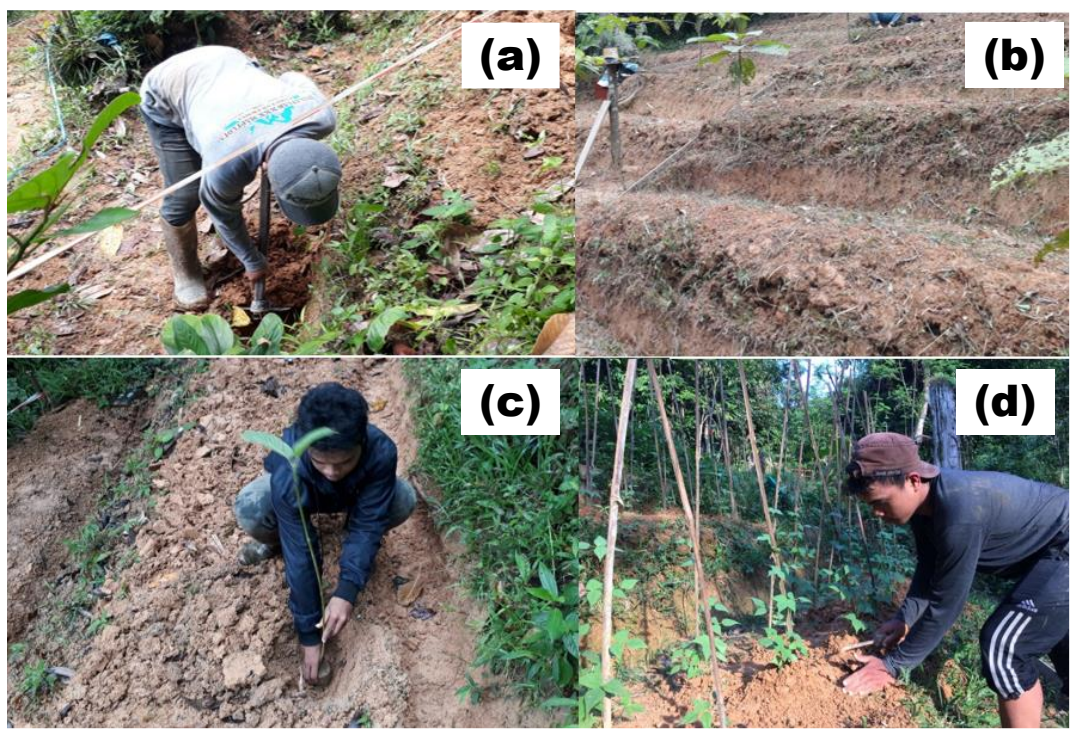

Figure 1. Photographs of: (a) land preparation, (b) terrace, (c) plantation of white jabon (Neolamarckia cadamba), and (d) maintenance of bean (Phaseolus vulgaris)

Table 1. Erosion hazard index

\begin{tabular}{cc}
\hline Erosion Hazard Index & Category \\
\hline$<1.00$ & Low \\
$1.01-4.00$ & Moderate \\
$4.01-10.00$ & High \\
$>10.01$ & Very high \\
\hline
\end{tabular}

Source: Arsyad (2010)

An erosion plot of size $3 \mathrm{~m} \times 10 \mathrm{~m}$ was built to obtain data on a surface run-off and eroded soil mass within each experimental plot. The measurement of hydro orological parameters was done for 30 rainy events from May to September of 2018. As a control plot, erosion data of (Karyati et al., 2018) from a moderate slope plot (> 8-15\%) without plantation were used.

\subsubsection{Growth parameters assessment}

The growth parameters of the plants were measured every month during the four months of observation. Four growth parameters of white jabon - healthy plant, survival rate, diameter, and height increments - were measured. The diameter and height increments of $N$. cadamba in the two slope classes were compared by performing a t-test. The growth parameters of bean - healthy plant, ground coverage, and yield - were also measured. The measurement criteria of plant growth followed the Regulation (Number P.60/Menhut-II/2009) of the Ministry of
Forestry of the Republic of Indonesia. The yield of beans was recorded by harvesting at the end of the observation period. Jabon trees were not cut down because they were planted for the purposes of soil and water conservation.

\subsubsection{Hydro orological aspect}

Based on data from 30 rainfall events, several hydro orological parameters, such as surface run-off, potential soil erosion rate, erosion hazard index, and erosion hazard level were measured/estimated. The erosion hazard index was calculated by dividing potential erosion rate by tolerable erosion rate. Based on Arsyad (2010), the categories of erosion hazard index are given in Table 1 . The erosion hazard level followed the Regulation (Number P4/VSET/2013; Table 2) of Directorate General of Watershed Management and Social Forestry, Ministry of Forestry, Republic of Indonesia. The potential for erosion in the three experimental plots (two slope classes and one control plot without planting) was compared by performing ANOVA test.

\subsubsection{Economic aspect}

The cost, revenue, and profit were calculated from implementation of bean as intercropping in white jabonbean agroforestry system. The assessment of feasibility and evaluation of economic benefits was done by calculating costs, revenue, and profit (Karmini, 2020; Tata et al., 2015).

Table 2. Classification of erosion hazard level

\begin{tabular}{|c|c|c|c|c|c|}
\hline \multirow{4}{*}{ Soil column (cm) } & \multicolumn{5}{|c|}{ Erosion class } \\
\hline & $\mathrm{I}$ & II & III & IV & V \\
\hline & \multicolumn{5}{|c|}{ Erosion rate (ton ha ${ }^{-1}$ year $^{-1}$ ) } \\
\hline & $<15$ & $15-<60$ & $60-<180$ & $180-480$ & $>480$ \\
\hline Deep (>90) & Very low & Low & Moderate & Heavy & Very heavy \\
\hline Intermediate (60-90) & Low & Moderate & Heavy & Very high & Very heavy \\
\hline Shallow $(30-<60)$ & Moderate & Heavy & Very heavy & Very heavy & Very heavy \\
\hline Very shallow $(<30)$ & Heavy & Very heavy & Very heavy & Very heavy & Very heavy \\
\hline
\end{tabular}

Source: Regulation of Directorate General of Watershed Management and Social Forestry, Ministry of Forestry, Republic of Indonesia Number: P.4/V-SET/2013 


\section{Results}

\subsection{Silvicultural aspect}

The growth parameters of $N$. cadamba and $P$. vulgaris in the two different slope classes are summarized in Table 3. The healthy plants of $N$. cadamba and $P$. vulgaris were categorized to good (80-90\%) on steep and very-steep slopes. The survival rate, diameter and height increments of $N$. cadamba were higher on steep slope than on very-steep slope. Similarly, ground coverage and yield of $P$. vulgaris were higher on steep slope compared to very-steep slope.

The growth parameters of the implemented vegetation ( $N$. cadamba - P. vulgaris) and terraces on the sloping lands were categorized moderate to good, except the ground coverage of $P$. vulgaris on very-steep slope that was in low category (60-69\%). The good criteria of healthy plants (80$89 \%$ ) of $N$. cadamba and $P$. vulgaris were observed on steep and very-steep slope classes. Similarly, the survival rate of $N$. cadamba on steep slope class was categorized as 'good'. The survival rate of $N$. cadamba on very-steep slope was moderate (70-79\%), while the ground coverage of $P$. vulgaris was moderate on steep slope. The increments in diameter $\left(1.78 \mathrm{~cm}_{\text {year }}{ }^{-1}\right)$ and height $\left(1.84 \mathrm{~m} \mathrm{year}^{-1}\right)$ of $N$. cadamba on steep slope were higher than those $(1.68 \mathrm{~cm}$ year $^{-1}$ and $1.53 \mathrm{~m}$ year $^{-1}$ ) on very-steep slope (Table 3 ).

\subsection{Hydro orological aspect}

The hydro orological parameters in vegetation ( $N$. cadamba- $P$. vulgaris) and terrace combination systems in the two different slope classes are presented in Table 4. Both the surface run-off rate and potential erosion rate were lower on steep slope than on very-steep slope. The erosion hazard index was also lower on a less steep slope compared with a more steep slope. The erosion hazard indices on the two slope classes were categorized as low. The erosion hazard class and erosion hazard level on both slope classes were included to very low class.

Table 4 provides the hydro orological parameters surface run-off, potential erosion rate, erosion hazard index, erosion hazard class, and erosion hazard level - in the vegetation ( $N$. cadamba-P. vulgaris) and terrace combination system for the two slope classes. The increase of soil slope gradient augmented the amount of surface runoff and potential erosion rate. An increase in soil slope was reported to an increase in soil erosion following quadratic function for several lands uses like forest, farm, orchard, and fallow land (Zhang et al., 2015). Applying a combination of vegetation and terracing techniques to soil with steep and very-steep slopes results in the similar erosion hazard class of very low and erosion hazard level very low. The length and slope steepness are important factors that affect the rate of surface run-off and eroded soil mass. The shape of the slope also affects soil erosion; concave slope forms are usually more stable and produce less sediment rather than planar (uniform) slope (Gray, 2016).

\subsection{Economic aspect}

Combination of vegetative planting ( $N$. cadamba - $P$. vulgaris) and terrace systems in different slope gradients requires expenditure for buying raw materials, depreciation of equipment, and wage of labor as given in Table 5. The implementation of this combination provides revenue and profit, especially from $P$. vulgaris yield. Table 5 reveals economic analysis of $P$. vulgaris as intercropping in vegetation ( $N$. cadamba - $P$. vulgaris) and terrace combination system on different slope classes. The earning of selling $P$. vulgaris was IDR 9,360,000.00 ha $\mathrm{h}^{-1}$ cropping season $^{-1}$ on steep slope and IDR 6,480,000.00 ha ${ }^{-1}$ cropping season $^{-1}$ on very-steep slope.

The economic analysis of the implementation of agroforestry ( $N$. cadamba $-P$. vulgaris) and terrace systems on steep and very-steep slope classes consists of production cost, revenue, and profit. The economic analysis of $P$. vulgaris as intercropping in agroforestry ( $N$. cadamba $-P$. vulgaris) and terrace combination system on the two different slope classes are given in Table 5 . The cost of raw material was required for buying $N$. cadamba seedling, $P$. vulgaris seed, string of raffia, organic fertilizer, NPK fertilizer, Tetrin, Garsil D, and Furadan. The depreciation cost was calculated for hoe, chopper, sickle, sprayer, and bucket. The labor cost was incurred for terracing, land preparation, planting, plantation maintenance, and harvesting (Table 5).

Besides production cost, the implementation of the proposed agroforestry and terrace systems generates revenue from $P$. vulgaris yield and profit. The revenue of $P$. vulgaris was IDR 9,360,000.00 $\mathrm{ha}^{-1}$ cropping season $^{-1}$ on steep slope class and IDR 6,480,000.00 ha $^{-1}$ cropping slope $^{-1}$ on very-steep slope class.

Table 3. The growth parameters of $N$. cadamba and $P$. vulgaris in two different slope classes

\begin{tabular}{|c|c|c|c|c|c|c|c|c|}
\hline $\begin{array}{c}\text { Slope } \\
\text { gradient }\end{array}$ & $\begin{array}{c}\text { Plant } \\
\text { species }\end{array}$ & $\begin{array}{l}\text { Healthy } \\
\text { plants (\%) }\end{array}$ & $\begin{array}{c}\text { Survival rate } \\
(\%)\end{array}$ & $\begin{array}{c}\text { Ground } \\
\text { coverage (\%) }\end{array}$ & $\begin{array}{c}\text { Yield } \\
\left(\mathrm{kg} \mathrm{ha}^{-1}\right)\end{array}$ & $\begin{array}{c}\text { Diameter } \\
\text { increment } \\
\left(\mathrm{cm}_{\text {year }}{ }^{-1}\right)\end{array}$ & & $\begin{array}{l}\text { Height increment } \\
\left(\mathrm{m} \text { year }^{-1}\right)\end{array}$ \\
\hline \multirow{2}{*}{$\begin{array}{c}\text { Steep } \\
\text { slope } \\
(>25-45 \%)\end{array}$} & $\begin{array}{c}N . \\
\text { cadamba }\end{array}$ & $\begin{array}{l}80-89 \\
\text { (Good) }\end{array}$ & $\begin{array}{c}80-89 \\
\text { (Good) }\end{array}$ & - & - & 1.78 & ns & 1.84 \\
\hline & P. vulgaris & $\begin{array}{l}80-89 \\
\text { (Good) }\end{array}$ & - & $\begin{array}{c}\text { 70-79 } \\
\text { (Moderate) }\end{array}$ & 520 & - & & - \\
\hline \multirow{2}{*}{$\begin{array}{l}\text { Very-steep } \\
\text { slope } \\
(>45 \%)\end{array}$} & $\begin{array}{c}N . \\
\text { cadamba }\end{array}$ & $\begin{array}{c}80-89 \\
\text { (Good) }\end{array}$ & $\begin{array}{c}\text { 70-79 } \\
\text { (Moderate) }\end{array}$ & - & - & 1.68 & & 1.53 \\
\hline & P. vulgaris & $\begin{array}{l}80-89 \\
\text { (Good) }\end{array}$ & - & $\begin{array}{l}\text { 60-69 } \\
\text { (Low) }\end{array}$ & 360 & - & & - \\
\hline
\end{tabular}

Notes: $\mathrm{ns}=$ not significant at the 0.05 level; $^{* *}=$ significant at the 0.01 level 
Table 4. The hydro orological parameters in vegetative (N. cadamba-P. vulgaris) and terrace combination system in the two different slope classes and a control plot without plantation

\begin{tabular}{|c|c|c|c|c|c|c|c|}
\hline $\begin{array}{l}\text { Slope } \\
\text { gradient }\end{array}$ & $\begin{array}{l}\text { Soil } \\
\text { depth } \\
(\mathrm{cm})\end{array}$ & $\begin{array}{l}\text { Surface runoff rate } \\
\left(\mathrm{m}^{3} \mathrm{ha}^{-1} \text { year }{ }^{-1}\right)\end{array}$ & $\begin{array}{c}\text { Potential erosion } \\
\text { rate } \\
\text { (ton } \mathrm{ha}^{-1} \text { year }^{-1} \text { ) }\end{array}$ & $\begin{array}{c}\text { Tolerable } \\
\text { erosion rate } \\
\text { 'ton } \text { ha }^{-1} \text { year }^{-1} \text { ) }\end{array}$ & $\begin{array}{c}\text { Erosion } \\
\text { hazard } \\
\text { index }\end{array}$ & $\begin{array}{c}\text { Erosion } \\
\text { hazard class }\end{array}$ & $\begin{array}{c}\text { Erosion } \\
\text { hazard } \\
\text { level }\end{array}$ \\
\hline$>25-45 \%$ & $>100$ & 691.77 & $2.22 \quad * *$ & $25^{1)}$ & 0.16 (Low) & Very low & Very low \\
\hline$>45 \%$ & $>100$ & 856.28 & 2.73 & $25^{1)}$ & 0.19 (Low) & Very low & Very low \\
\hline$>8-15 \%^{2)}$ & $>100$ & 1012.21 & 45.53 & $25^{1)}$ & $\begin{array}{c}1.82 \\
\text { (Moderate) }\end{array}$ & Low & Low $^{3)}$ \\
\hline
\end{tabular}

Note: $* *$ significant at $\mathrm{p} \leq 0.01$

${ }^{1)}$ The tolerable erosion rate was estimated $25 \mathrm{ton} \mathrm{ha}^{-1} \mathrm{year}^{-1}$ for the effective soil depth of $>100 \mathrm{~cm}$ (Ardiansyah et al., 2013)

${ }^{2)}$ No plantation

${ }^{3)}$ Karyati et al. (2018)

The cost due to loss of $N$. cadamba and $P$. vulgaris plantations was IDR 2,427,500.00 ha ${ }^{-1}$ cropping season $^{-1}$ and IDR 5,307,500.00 ha-1 cropping season ${ }^{-1}$ on steep and verysteep slope classes, respectively (Table 5 ). Although there was no profit in the first cropping season from the application of planting $N$. cadamba $-P$. vulgaris in two different slope classes, the revenue was gained from selling $P$. vulgaris. In addition, the benefit of conservation and environmental aspects would be obtained from $N$. cadamba trees on sloping lands. The $N$. cadamba trees are not generally planned to be felt until a minimum age of 6 years when the plants become suitable for harvest.

\section{Discussion}

The application of a combination of planting $N$. cadamba-P. vulgaris and terraces will provide advantages based on silvicultural, hydro-orological, and economic aspects when compared to sloping lands that are not planted or used. The $N$. cadamba-P. vulgaris combination on steep and very-steep slopes improved survival rate, ground coverage, and yield of $P$. vulgaris. This increased the diameter and height of $N$. cadamba (Table 3 ), reduced the rate of surface run-off and potential soil erosion (Table 4), and added economic benefit of revenue from selling $P$. vulgaris's yield (Table 5). The improvement of survival rate, ground coverage, and yield production on sloping soils (Tabel 3 ) indicated that $P$. vulgaris has the ability to grow and adapt on critical lands, such as low soil phosphorus and moisture deficit conditions in soils (Margaret et al., 2014), and drought-stress conditions (Darkwa et al., 2016). In addition, the performance of $P$. vulgaris grown as intercropping can be determined by cropping season, agroecological zones, and plant combination design (Nassary et al., 2020).

The yield of $P$. vulgaris was $520 \mathrm{~kg} \mathrm{ha}^{-1}$ on steep slope gradient and $360 \mathrm{~kg} \mathrm{ha}^{-1}$ on very-steep slope gradient (Table 3). These yields were lower compared to the average yield reported for the East Kalimantan province $\left(8,120 \mathrm{~kg} \mathrm{ha}^{-1}\right)$ and Samarinda City (11.480 kg ha $\left.{ }^{-1}\right)$ in 2018 (BPS - Statistics of Kalimantan Timur Province, 2019) as well as for the National yield $\left(12,170 \mathrm{~kg} \mathrm{ha}^{-1}\right.$ ) (BPS - Statistics Indonesia, 2019). Although the productivity of $P$. vulgaris in this study was relatively low, it appeared that based on several other growth parameters $P$. vulgaris could thrive on soils including steep slopes (steep to very steep gradients). This is advantageous in terms of the use of vacant lands among $N$. cadamba in the early years of implementation of the agroforestry and terrace systems.

The diameter and height increments of N. cadamba, planted as forestry plants in agroforestry system ( $N$. cadamba - P. vulgaris) on the steep slope class, were higher than those planted on very-steep slope class. Similar results were also reported for combination of N. cadamba-G. max (Karyati et al., 2018). Although the diameter increment of $N$. cadamba, planted in steep and very-steep slopes, was not significantly different ( $p \leq 0.05)$, the height increment of $N$. cadamba on the two slope gradients was highly significant. The diameter increment of $N$. cadamba, planted in the agroforestry of $N$. cadamba $-P$. vulgaris on a steep slope class ( $1.78 \mathrm{~cm}_{\text {year }}{ }^{-1}$ ) (Table 3 ), was greater compared with those planted in agroforestry of $N$. cadamba $-G$. max on the same steep slope (1.5 cm year ${ }^{-1}$ ) (Karyati et al., 2018). The diameter and height increments of $N$. cadamba, planted as forestry plants in agroforestry on sloping land, showed quite good results compared to that grown as a monoculture crop. Krisnawati et al. (2011) reported the diameter and height increment of 1.2-4.8 cm year ${ }^{-1}$ and 0.8-3.7 m year ${ }^{-1}$, respectively for $N$. cadamba in South Kalimantan.

Reduced soil erosion obtained with the application of a combination of planting $N$. cadamba and $P$. vulgaris on sloping land was due to a lower rate of surface run-off (Table 4); the lower surface run-off rate minimized soil transport during intensive rainfall (He et al., 2014; Kovář et al., 2012). The reduction of surface run-off and eroded soil mass is more effective with the application of terraces at the study site. The combined application of planting several types of crops and terraces results in different run-off and soil erosion rates (Karyati \& Sarminah, 2018). The crowns of $N$. cadamba trees play a role in reducing the speed of rainfall on the ground, thereby reducing the kinetic energy that damages the soil particles. 
Table 5. Economic analysis of $P$. vulgaris as intercropping in vegetation ( $N$. cadamba-P.vulgaris) and terrace combination system in the plots on steep slope and very-steep slope

\begin{tabular}{|c|c|c|c|c|c|c|}
\hline No. & Item & Quantity & Unit & Price (IDR) & Unit & $\begin{array}{c}\text { Total } \\
\left(\text { (IDR ha }^{-1} \text { cropping season }^{-1}\right)\end{array}$ \\
\hline \multicolumn{7}{|c|}{ Production cost (Steep slope and very-steep slope plots) } \\
\hline \multicolumn{7}{|c|}{ Raw materials cost } \\
\hline 1 & N. cadamba seedling & $1,600.00$ & seedling ha ${ }^{-1}$ cropping season $^{-1}$ & $1,500.00$ & seedling ${ }^{-1}$ & $2,400,000.00$ \\
\hline 2 & P. vulgaris seed & 25.00 & $\mathrm{~kg} \mathrm{ha}^{-1}$ & $55,000.00$ & pack $^{-1}$ & $1,375,000.00$ \\
\hline 3 & String of raffia & 50.00 & units ha ${ }^{-1}$ & $10,000.00$ & units $^{-1}$ & $500,000.00$ \\
\hline 4 & Organic fertilizer & 50.00 & gunny sack ha ${ }^{-1}$ & $20,000.00$ & gunny sack ${ }^{-1}$ & $1,000,000.00$ \\
\hline 5 & NPK fertilizer & 50.00 & pack ha ${ }^{-1}$ & $15,000.00$ & pack $^{-1}$ & $750,000.00$ \\
\hline 6 & Urea fertilizer & 50.00 & pack ha ${ }^{-1}$ & $8,000.00$ & pack $^{-1}$ & $400,000.00$ \\
\hline 7 & TSP fertilizer & 250.00 & $\mathrm{~kg} \mathrm{ha}^{-1}$ cropping season $^{-1}$ & $6,000.00$ & $\mathrm{~kg}^{-1}$ & $1,500,000.00$ \\
\hline 8 & Tetrin & 50.00 & bottle ha-1 & $10,000.00$ & pack $^{-1}$ & $500,000.00$ \\
\hline 9 & Garsil D & 50.00 & pack ha ${ }^{-1}$ & $10,000.00$ & unit $^{-1}$ & $500,000.00$ \\
\hline \multirow[t]{2}{*}{10} & Furadan & 50.00 & pack ha ${ }^{-1}$ & $15,000.00$ & unit $^{-1}$ & $750,000.00$ \\
\hline & Subtotal & & & & & $9,675,000.00$ \\
\hline \multicolumn{7}{|c|}{ Depreciation cost } \\
\hline 11 & Hoe & 2.00 & unit ha-1 & $150,000.00$ & unit $^{-1}$ & $50,000.00$ \\
\hline 12 & Chopper & 2.00 & unit ha-1 & $120,000.00$ & unit $^{-1}$ & $40,000.00$ \\
\hline 13 & Sickle & 2.00 & unit ha-1 & $60,000.00$ & unit $^{-1}$ & $20,000.00$ \\
\hline 14 & Sprayer & 1.00 & unit ha ${ }^{-1}$ & $350,000.00$ & unit $^{-1}$ & $35,000.00$ \\
\hline \multirow[t]{2}{*}{15} & Bucket & 2.00 & unit ha ${ }^{-1}$ & $10,000.00$ & unit $^{-1}$ & $5,000.00$ \\
\hline & Subtotal & & & & & $150,000.00$ \\
\hline \multicolumn{7}{|c|}{ Labourers cost } \\
\hline 16 & Terracing & 50.00 & days ha ${ }^{-1}$ cropping season $^{-1}$ & $100,000.00$ & day $^{-1}$ & $5,000,000.00$ \\
\hline 17 & Land preparation & 12.50 & days ha ${ }^{-1}$ cropping season $^{-1}$ & $100,000.00$ & day $^{-1}$ & $1,250,000.00$ \\
\hline 18 & Planting & 12.50 & days ha ${ }^{-1}$ cropping season $^{-1}$ & $100,000.00$ & day $^{-1}$ & $1,250,000.00$ \\
\hline \multirow[t]{4}{*}{19} & Plantation maintenance & & & & & \\
\hline & a. Replanting & 12.50 & days ha ${ }^{-1}$ cropping season $^{-1}$ & $100,000.00$ & day $^{-1}$ & $1,250,000.00$ \\
\hline & b. Fertilizing & 12.50 & days ha ${ }^{-1}$ cropping season $^{-1}$ & $100,000.00$ & day $^{-1}$ & $1,250,000.00$ \\
\hline & c. Control pest and diseases & 25.00 & days ha ${ }^{-1}$ cropping season $^{-1}$ & $100,000.00$ & day $^{-1}$ & $2,500,000.00$ \\
\hline \multirow[t]{2}{*}{20} & Harvesting & 12.50 & days ha-1 cropping season $^{-1}$ & $100,000.00$ & day $^{-1}$ & $1,250,000.00$ \\
\hline & Subtotal & 137.50 & days ha ${ }^{-1}$ cropping season $^{-1}$ & $100,000.00$ & day $^{-1}$ & $13,750,000.00$ \\
\hline \multicolumn{4}{|c|}{ Total cost of $N$. cadamba and $P$. vulgaris plantation } & & & $23,575,000.00$ \\
\hline \multicolumn{4}{|c|}{ Steep slope plot (>25-45\%) } & & & $11,787,500.00$ \\
\hline \multicolumn{4}{|c|}{ Very-steep slope plot (>45\%) } & & & $11,787,500.00$ \\
\hline \multicolumn{7}{|c|}{ Revenue from $P$. Vulgaris } \\
\hline \multicolumn{2}{|c|}{ Steep slope plot (>25-45\%) } & 520.00 & $\mathrm{~kg} \mathrm{ha}^{-1}$ & $18,000.00$ & $\mathrm{~kg}$ & $9,360,000.00$ \\
\hline \multicolumn{2}{|c|}{ Very-steep slope plot (>45\%) } & 360.00 & $\mathrm{~kg} \mathrm{ha}^{-1}$ & $18,000.00$ & $\mathrm{~kg}$ & $6,480,000.00$ \\
\hline \multicolumn{2}{|c|}{ Total } & & & & & $15,840,000.00$ \\
\hline \multicolumn{7}{|c|}{ Profit } \\
\hline \multicolumn{3}{|c|}{ Steep slope plot (>25-45\%) } & & & & $-2,427,500.00$ \\
\hline \multicolumn{3}{|c|}{ Very-steep slope plot (>45\%) } & & & & $-5,307,500.00$ \\
\hline \multicolumn{3}{|c|}{ Total } & & & & $-7,735,000.00$ \\
\hline
\end{tabular}

The type and cover of vegetation are important factors that influence the activity of geomorphological processes by controlling the dynamics of surface runoff and sediment (Blinkova \& Lavrov, 2017). The shape of the slope also has a significant impact on soil erosion and surface runoff which are greater on lands with a uniform slope than on lands with convex and concave slopes (Sensoy \& Kara, 2014). The presence of $P$. vulgaris as an intercropping plant covering more than $60 \%$ of land surface also slows down the run-off rate (Table 3). A reduction in surface run-off has the potential to reduce eroded soil mass, both on steep and very-steep slopes. Although the erosion hazard indices in the two studied plots are categorized as low (Table 4), the erosion hazard index on the steep slope class is lower (0.16) than that on the very-steep slope class (0.19). There was a very significant difference between the runoff and potential erosion rates in the two studied plots and the control plot without planting.

Soil erosion on land with application of agroforestry and terraces on sloping land is smaller than on the land with a combination of soil-water conservation techniques and agroforestry (Sumarno et al., 2011) and agroforestry ( $N$. 
cadamba - Glycine max and F. moluccana - Arachis hypogaea) in slightly steep and steep slopes (Karyati et al., 2018; Sarminah et al., 2018). However, our results showed that combination of planting $N$. cadamba - P. vulgaris and terraces on land with steep and very-steep slopes resulted in greater soil erosion than the combined planting of $F$. moluccana - V. cylindrica and terraces on two classes of the same slope (Karyati et al., 2019). Moreover, forest canopy and crop cover play a role in restraining the rate of rainwater and reducing surface runoff and eroded soil mass.

The implementation of vegetation and terrace in the study plots resulted in lower surface run-off rate, potential erosion rate, and erosion hazard index compared to the mixed cropping of $N$. cadamba and Glycine max on a slightly steep slope (>15-25\%) and a steep slope (>25-45\%) as well as on a moderate slope $(>8-15 \%)$ without plantation (Karyati et al., 2018). This practice also induced lower surface runoff, potential erosion rate, and erosion hazard index rather than the implementation $F$. moluccana and $A$. hypogaea on steep plots (Sarminah et al., 2018). Lands with moderate slopes have a high hydraulic conductivity value, which results in low soil erosion. The amount of erosion can be determined by the application of conservation techniques in the area (Siswanto \& Sule, 2019).

Apart from the benefits obtained from the silvicultural and hydro-orological aspects, the combination of planting seasonal crops among forestry plants on sloping land can provide economic benefits from selling the seasonal crops (Table 5). This will increase the income of farmers in the early years of applying the combination of agroforestry and terraces on sloping lands. The agroforestry systems have many important roles in increasing agronomic productivity, co-production of a variety of food and non-food products, and ecosystem service providers (Lehmann et al., 2020). Utilization of the empty space between forestry plants with planting ground cover crops can be done in the early years of applying soil and water conservation techniques until the canopy of forestry plants is linked. The revenue obtained from the selling of seasonal crops will be the only source of economic benefit since the planted forestry crops will not be cut down. The application of mixed crops with agroforestry systems provides benefits from environmental, social and economic aspects, as well as increases rural economic development (Bijarpas et al., 2015).

The profit of $P$. vulgaris cultivation in implementing agroforestry ( $N$. cadamba and $P$. vulgaris) and terrace on sloping lands (Table 5) was higher than Arachis hypogaea, Glycine max, Vigna cylindrica, and Sorghum bicolor yields as intercropping in an agroforestry system (Karmini et al., 2017; Karyati et al., 2020; Karyati et al., 2019). The total costs, total revenue, and profit of application of $A$. hypogaea as an intercropping in the agroforestry of $F$. moluccana and $A$. hypogaea were IDR 10,985,000.00 $\mathrm{ha}^{-1}$ cropping season $^{-1}$, IDR 14.000.000,00 ha $^{-1}$ cropping season ${ }^{-1}$, and IDR 3,015,000.00 ha ha $^{-1}$ cropping season ${ }^{-1}$ (Table 5). The application of $G$. max in $N$. cadamba $-G$ max agroforestry spent total costs of IDR $11,019,000.00 \mathrm{ha}^{-1}$ cropping season1 , total revenue of IDR 3,500,000.00 ha ${ }^{-1}$ cropping season $^{-1}$; and profit of IDR 7,519,000.00 $\mathrm{ha}^{-1}$ cropping season ${ }^{-1}$, respectively (Karmini et al., 2017). Similarly, the implementation of vegetations (sengon and sorghum) and terrace methods combination on the steep slope expended total costs of $9,181,128.47$ IDR ha ${ }^{-1}$ cropping season $^{-1}$ and resulted in total revenue of IDR $1,800,000.00 \mathrm{ha}^{-1}$ cropping season $^{-1}$; and profit of (-) IDR 7,181,128.47 ha ${ }^{-1}$ cropping season $^{-1}$, respectively. The total costs, total revenue, and profit of implementation of this combination on the steeper ground were IDR 9,181,128.47 $\mathrm{ha}^{-1}$ cropping season $^{-1}$, IDR $650,000.00$ ha $^{-1}$ cropping season $^{-1}$, and (-)IDR 8,531,128.47 ha $^{-1}$ cropping season $^{-1}$, respectively (Karyati et al., 2020). Karyati et al. (2019) reported that the implementation vegetatives ( $F$. molucccana $-V$. cylindrica) and terrace on steep slope gradient gave total costs of $16,135,000.00$ IDR $\mathrm{ha}^{-1}$ cropping season $^{-1}$, total revenue of IDR 20,000,000.00 $\mathrm{ha}^{-1}$ cropping season $^{-1}$, and profit of 3,865,000.00 $\mathrm{ha}^{-1}$ cropping season $^{-1}$. Meanwhile, the economic analysis of this implementation on very slope gradient showed total costs, total revenue, and profit were IDR 16,135,000.00 ha $\mathrm{ha}^{-1}$ cropping season $^{-1}$; IDR $16,800,000.00$ ha $^{-1}$ cropping season $^{-}$ 1; and IDR 665,000.00 ha ${ }^{-1}$ cropping season $^{-1}$, respectively. Labor cost for terracing comprises the highest cost. If no terracing were applied in site preparation, it would be profitable for adapting agroforestry technique in steep slope. However, if $P$. vulgaris is planted on flat to slightly steep slope land, no terracing will be required. It is estimated that $P$. vulgaris will be more productive and profitable than the results obtained in this study.

The combination of vegetation and terraces is able to improve silvicultural aspects, soil and water conservation, as well as the economy on sloping land through improving plant quality, reducing run-off and erosion rates, and increasing economic value. The choice of combination of forestry and agricultural crops is a key factor in the agroforestry system. The selected plant species must be able to grow and adapt to low soil fertility and high soil acidity as well as contribute organic nutrients to the soil that can support plant productivity.

\section{Conclusion}

The application of agroforestry on sloping lands that combines the vegetative and terrace methods can be considered suitable based on silvicultural, hydro orological, and economic aspects. Agricultural crops, planted as intercropping with forestry crops, provide additional economic value in the short term. While forestry crops provide benefits of soil and water conservations from silvicultural and hydro orological aspects by reducing the rate of surface run-off and eroded soil mass in the long term. Moreover, biogeophysical, social, and cultural aspects also play an important role in supporting the successful application of agroforestry and terracing as part of the effort of a sustainable land-use system in Indonesia.

\section{Declaration of Competing Interest}

The authors declare no competing financial or personal interests that may appear and influence the work reported in this paper. 


\section{References}

Agus, F., Husnain, H., \& Yustika, R. D. (2015). Improving agricultural resilience to climate change through soil management. Jurnal Penelitian dan Pengembangan Pertanian, 34(4), 147-158. https://doi.org/http://dx.doi.org/10.21082/jp3.v34n4 .2015.p147-158

Ardiansyah, T., Lubis, K. S., \& Hanum, H. S. (2013). Kajian tingkat bahaya erosi di beberapa penggunaan lahan di kawasan hilir Daerah Aliran Sungai (DAS) Padang. Jurnal Agroekoteknologi Universitas Sumatera Utara, 2(1), 97617. https://jurnal.usu.ac.id/index.php/agroekoteknologi/ article/view/5861/0

Arsyad, S. (2010). Konservasi Tanah dan Air. IPB Press, Bogor, Indonesia. ISBN: 978- 493-003-2.

Bijarpas, M. M., Shahraji, T. R., \& Limaei, S. M. (2015). Socioeconomic evaluation of agroforestry systems (Case study: Northern Iran). Journal of Forest Science, 61(11), 478-484. https://doi.org/10.17221/30/2015JFS

Blinkova, O., \& Lavrov, V. (2017). Study of soil water-erosion intensity and vegetation cover of an oak-spruce forest in the Pokutsko-Bukovina Carpathians, Ukraine. Archives of Biological Sciences, 69(4), 627-636. https://doi.org/10.2298/ABS161206008B

BPS - Statistics Indonesia. (2019). Statistik Tanaman Sayuran dan Buah-buahan Semusim Indonesia 2018. BPS Statistics Indonesia.

BPS - Statistics of Kalimantan Timur Province. (2019). Provinsi Kalimantan Timur dalam Angka 2018. Samarinda, Kalimantan Timur: BPS - Statistics of Kalimantan Timur Province.

Cotler, H., \& Cuevas, M. L. (2019). Adoption of soil conservation practices through knowledge governance: the Mexican experience. Journal of Soil Science and Environmental Management, 10(1), 1-11. https://doi.org/10.5897/JSSEM2018.0714

Darkwa, K., Ambachew, D., Mohammed, H., Asfaw, A., \& Blair, M. W. (2016). Evaluation of common bean (Phaseolus vulgaris L.) genotypes for drought stress adaptation in Ethiopia. The Crop Journal, 4(5), 367376. https://doi.org/10.1016/j.cj.2016.06.007

Fuady, Z., Satriawan, H., \& Mayani, N. (2015). Aliran Permukaan, Erosi dan Hara Sedimen Akibat Tindakan Konservasi Tanah Vegetatif pada Kelapa Sawit (Vol. 11) [erosion; nutrients; runoff; sediment; soil conservation].

https://doi.org/10.15608/stjssa.v11i2.225

Gray, D. (2016). Effect of slope shape on soil erosion. Journal of Civil and Environmental Engineering, 6(3), 1-2. https://doi.org/10.4172/2165-784X.1000231

Handayani, S. W., Fauzan, M., \& Nasihuddin, A. A. (2018). Conversion of Agricultural Land Policy in Indonesia. Proceedings of the 5th International Conference on Community Development (AMCA 2018), 252-254. https://doi.org/10.2991/amca-18.2018.69

He, Z., Weng, H., Ho, H.-C., Ran, Q., \& Mao, M. (2014). Soil erosion and pollutant transport during rainfall-runoff processes. Water Resources, 41(5), 604-611. https://doi.org/10.1134/S0097807814050170

Hidayat, Y., Murtilaksono, K., \& Sinukaban, N. (2012). Characterization of surface runoff, soil erosion and nutrient loss on forest-agriculture landscape. Journal of Tropical Soils, 17(3), 259-266. https://journal.unila.ac.id/index.php/tropicalsoil/artic le/view/160

Hoang, L. T., Roshetko, J. M., Huu, T. P., Pagella, T., \& Mai, P. N. (2017). Agroforestry - The Most Resilient Farming System for the Hilly Northwest of Vietnam [Agroforestry development; farming systems; northwestern Vietnam; livelihoods' improvement; agroforestry adoptions]. 2017, 23. https://doi.org/10.20956/ijas.v5i1.1166

Karmini. (2020). Dasar-dasar Agribisnis. Samarinda: Mulawarman University Press. ISBN: 978-623-748031-0.

Karmini, Sarminah, S., \& Karyati. (2017). Economic analysis of groundnut (Arachis hypogaea) and soybean (Glycine max) as intercropping plants in two agroforestry systems. Biodiversitas: Journal of Biological Diversity, 18(2), 483-493. https://doi.org/10.13057/biodiv/d180206

Karyati, Santoso, A. E., Syafrudin, M., \& Karmini. (2020). Silvicultural and economic aspects on combination of vegetatives (Falcataria moluccana-Sorghum bicolor L.) and terrace methods in the different slope lands. IOP Conference Series: Earth and Environmental Science, 449, 012014. https://doi.org/10.1088/1755$1315 / 449 / 1 / 012014$

Karyati, \& Sarminah, S. (2018). Teknologi Konservasi Tanah dan Air. Samarinda: Mulawarman University Press. ISBN: 978-602-6834-59-1.

Karyati, Sarminah, S., Karmini, Simangunsong, G., \& Tamba, J. (2018). The mixed cropping of Anthocephalus cadamba and Glycine max for rehabilitating sloping lands. Biodiversitas Journal of Biological Diversity, 19(6), 2088-2095. https://doi.org/10.13057/biodiv/d190614

Karyati, K., Sarminah, S., Karmini, K., Rujehan, R., Lestari, V. F. E., \& Panorama, W. S. (2019). Silvicultural, hydroorological and economic aspects of a combination of vegetative (Falcataria moluccana-Vigna cylindrica) and terrace systems in soils of different slopes. Biodiversitas Journal of Biological Diversity, 20(8), 2308-2315. https://doi.org/10.13057/biodiv/d200828

Kovář, P., Vaššová, D., \& Janeček, M. (2012). Surface runoff simulation to mitigate the impact of soil erosion, case study of Trebsín (Czech Republic). Soil and Water Research, 7(3), 85-96. https://doi.org/10.17221/50/2011-SWR

Krisnawati, H., Kallio, M., \& Kanninen, M. (2011). Anthocephalus cadamba Miq. Ecology silviculture and productivity. Bogor. Bogor: Center for International Forestry Research (CIFOR). ISBN 978-602-8693-38-7.

Lehmann, L. M., Smith, J., Westaway, S., Pisanelli, A., Russo, G., Borek, R., Sandor, M., Gliga, A., Smith, L., \& Ghaley, B. B. (2020). Productivity and Economic 
Evaluation of Agroforestry Systems for Sustainable Production of Food and Non-Food Products. Sustainability, 12(13), 5429. https://www.mdpi.com/2071-1050/12/13/5429

Margaret, N., Tenywa, J. S., Otabbong, E., Mubiru, D. N., \& Ali, T. (2014). Development of Common Bean (Phaseolus Vulgaris L.) Production Under Low Soil Phosphorus and Drought in Sub-Saharan Africa: A. Journal of Sustainable Development, 7(5), 128-139. https://doi.org/10.5539/jsd.v7n5p128

Mushir, A., \& Kedru, S. (2012). Soil and water conservation management through indigenous and traditional practices in Ethiopia: A case study. Ethiopian Journal of Environmental Studies and Management, 5(4), 343-355.

https://doi.org/http://dx.doi.org/10.4314/ejesm.v5i4. 3

Nassary, E. K., Baijukya, F., \& Ndakidemi, P. A. (2020). Assessing the Productivity of Common Bean in Intercrop with Maize across Agro-Ecological Zones of Smallholder Farms in the Northern Highlands of Tanzania. Agriculture, 10(4), 117. https://doi.org/10.3390/agriculture10040117

Panagos, P., Standardi, G., Borrelli, P., Lugato, E., Montanarella, L., \& Bosello, F. (2018). Cost of agricultural productivity loss due to soil erosion in the European Union: From direct cost evaluation approaches to the use of macroeconomic models. Land Degradation \& Development, 29(3), 471-484. https://doi.org/10.1002/Idr.2879

Romadlon, F., \& Nurisusilawati, I. (2019). Implementasi Rumah Kemas Pada Rantai Pasok Baby Buncis Kualitas Ekspor. Jurnal Ilmiah Teknik Industri, 18(2), 203-212. https://doi.org/10.23917/jiti.v18i2.8689

Sarminah, S., Karyati, Karmini, Simbolon, J., \& Tambunan, E. (2018). Rehabilitation and soil conservation of degraded land using sengon (Falcataria moluccana) and peanut (Arachis hypogaea) agroforestry system. Biodiversitas Journal of Biological Diversity, 19(1), 222-228. https://doi.org/10.13057/biodiv/d190130

Sensoy, H., \& Kara, O. (2014). Slope shape effect on runoff and soil erosion under natural rainfall conditions [Slope shape effect on runoff and soil erosion under natural rainfall conditions] [Research Articles]. iForest - Biogeosciences and Forestry, 7(2), 110-114. https://doi.org/10.3832/ifor0845-007

Siswanto, S. Y., \& Sule, M. I. S. (2019). The Impact of slope steepness and land use type on soil properties in
Cirandu Sub-Sub Catchment, Citarum Watershed. IOP Conference Series: Earth and Environmental Science, 393, 012059. https://doi.org/10.1088/17551315/393/1/012059

Sollen-Norrlin, M., Ghaley, B. B., \& Rintoul, N. L. J. (2020). Agroforestry Benefits and Challenges for Adoption in Europe and Beyond. Sustainability, 12(17), 7001. https://doi.org/10.3390/su12177001

Sudrajat, D. J., Siregar, I. Z., Khumaida, N., Siregar, U. J., \& Mansur, I. (2015). Adaptability of White Jabon (Anthocephalus cadamba Miq.) Seedling from 12 Populations to Drought and Waterlogging [Anthocephalus cadamba; genotype; growth; population; stress tolerance index]. AGRIVITA Journal of Agricultural Science, 37(2), 130-143. https://doi.org/10.17503/agrivita.v37i2.455

Sumarno, Winarno, J., \& Prastomo, I. (2011). Kajian Pengelolaan Lahan Berdasarkan Tingkat Bahaya Erosi dan Pola Konservasi Tanah dan Air di Desa Ngadipiro Kecamatan Nguntoronadi, Kabupaten Wonogiri. Sains Tanah - Journal of Soil Science and Agroclimatology, 8(1), 13-22. https://jurnal.fp.uns.ac.id/index.php/tanah/article/vi ew/30

Tata, H. L., Bastoni, Sofiyuddin, M., Mulyoutami, E., Perdana, A., \& Janudianto. (2015). Jelutung Rawa: Teknik Budidaya dan Prospek Ekonominya. World Agroforestry Centre (ICRAF). ISBN: 978-979-3198-781.

Wahyudi. (2012). Analisis Pertumbuhan dan Hasil Tanaman Jabon (Anthocephallus cadamba). PERENNIAL, 8(1), 19-24. https://doi.org/10.24259/perennial.v8i1.210

Widuri, L. I., Lakitan, B., Sodikin, E., Hasmeda, M., Meihana, M., Kartika, K., \& Siaga, E. (2018). Shoot and Root Growth in Common Bean (Phaseolus vulgaris L.) Exposed to Gradual Drought Stress [Drought stress; Growth analysis; Riparian wetland; Stress recovery; Water deficit]. 2018, 40(3), 11. https://doi.org/10.17503/agrivita.v40i0.1716

Wolde, Z. (2015). The Role of Agroforestry in Soil and Water Conservation. LAMBERT Academic Publishing.

Zhang, Z., Sheng, L., Yang, J., Chen, X.-A., Kong, L., \& Wagan, B. (2015). Effects of Land Use and Slope Gradient on Soil Erosion in a Red Soil Hilly Watershed of Southern China. Sustainability, 7(10), 14309-14325. https://doi.org/10.3390/su71014309 